\title{
Georesources and Environment
}

IJGE 2018 4(2): 40-48

http://ijge.camdemia.ca, ijge@camdemia.ca

Available at http://ojs.library.dal.ca/ijge

\section{Field Investigation}

\section{Origin of Riverbed Sediments along the International Karakorum Highway, Pakistan}

\author{
Yingyan Zhu ${ }^{1,2, *}$, Zhiquan Yang ${ }^{3}$, Liping Liao $^{4}$, Muhammad Waseem ${ }^{5}$ \\ ${ }^{1}$ Key Laboratory of Mountain Hazards and Earth Surface Processes, Institute of Mountain Hazards and Environment, \\ Chinese Academy of Sciences, Chengdu China 610041 \\ ${ }^{2}$ University of Chinese Academy of Sciences, Beijing China 100049 \\ ${ }^{3}$ Kunming University of Science and Technology, Kunming China 650093 \\ ${ }^{4}$ Guanxi University, Guanxi China 530004 \\ ${ }^{5}$ National Centre of Excellence in Geology, University of Peshawar, Pakistan.
}

\begin{abstract}
A total of 45 riverbed sediment samples collected from the Khunjerab River, the Huza River, the Gilgit River and the India River along the International Karakoram Highway were compared and analyzed. The sample's mean, median, sorting coefficient, skewness and kurtosis, etc. were analyzed, and the relationship between the particle size distribution of sediments collected along the highway and debris flow sediments collected in the neighboring gullies was discussed. The results showed that river sediments were mainly derived from debris flow sediments, and the sediments had the similar distribution characteristics with debris flow composition.
\end{abstract}

Keywords: riverbed sediment, particle size distribution, granularity parameter, debris flow, KKH

\section{Introduction}

The China-Pakistan Highway is an international road connecting Kashgar, a city in western China, and Thakot, a city in northern Pakistan. It is also known as the International Karakoram Highway (KKH) (Figure 1). As the only land transportation between China and Pakistan, KKH promotes the economic and cultural exchanges between the two countries and has important strategic significance.

The unique geology, geomorphology, hydrology and climatic environment over the Highway area have formed a glaciated geohazard environment. The Highway is located on the west of the Himalayas as well as the Karakoram, a transition zone connecting the northern margin of the Pamirs and the southern plains of Pakistan. The regional terrain is generally inclined from north to south. The area is characterized with high mountains, snow-capped peaks, deep canyons, active glaciers, and turbulent rivers. Along the Highway, there are 44 peaks standing at an altitude of over 7,300 m. The Highway area has the largest land glacier accumulation with the exception of the polar (Mool et al 2005). Strong glacier movements and the associated erosions, combined with abundant precipitation, high topographic differences, distinct vertical climate, and frequent seismic activities, all of them contributed to abundant loose solid material reserves and produced a geo-environment prone to geologic hazards. Along the Highway, geological disasters such as snow avalanches, riverbank collapses, rock falls, landslides, and glacier advances frequently occurred (Group 1979, Shi and Wang 1980, Shi et al 1980, Zhang 1980, 1984). For example, on January 4, 2010, at K656 of KKH Upgrading Project, Attabud Village, on the west bank of the Hunza River, due to infiltration of glacial lakes and ice wedging into rock cuttings, it occurred massive landslide (N36 $18^{\prime} 10^{\prime \prime}$, E74²9'50"), transiently blocked Hunza valley, then completely submerged $\mathrm{KKH}$ by backwater, forming a $23 \mathrm{~km}$ long lake (Zhu et al 2014a, b). The Highway was forced to change its route and it had taken more than three years to rebuild it.

In February 2008, the First Phase of the KKH Upgrading Project (Raikot Bridge-Khunjerab Port) was officially launched, with a total length of 1,332 km. On April 28, 2016, the KKH Upgrading Project Phase II (Thakot to Havelian) was officially launched. The construction encountered difficulties in the prevention and control of geological disasters. Debris flows had been raging for years. They discharged into rivers, silting road or washing it away. It is quite believed that the riverbed deposits along the Highway were closely related to debris flow sediments. This paper analyzed the grain sizes of 45 riverbed deposit samples from $\mathrm{K} 670+990$ to $\mathrm{K} 808+700$ along $\mathrm{KKH}$ and compared the grain size distribution characteristics with debris flow sediments collected nearby for a better understanding of geohazard nature.

* Corresponding Author: Yingyan Zhu, Email: zh y y@,imde.ac.cn; Tel:+86 13060061919 


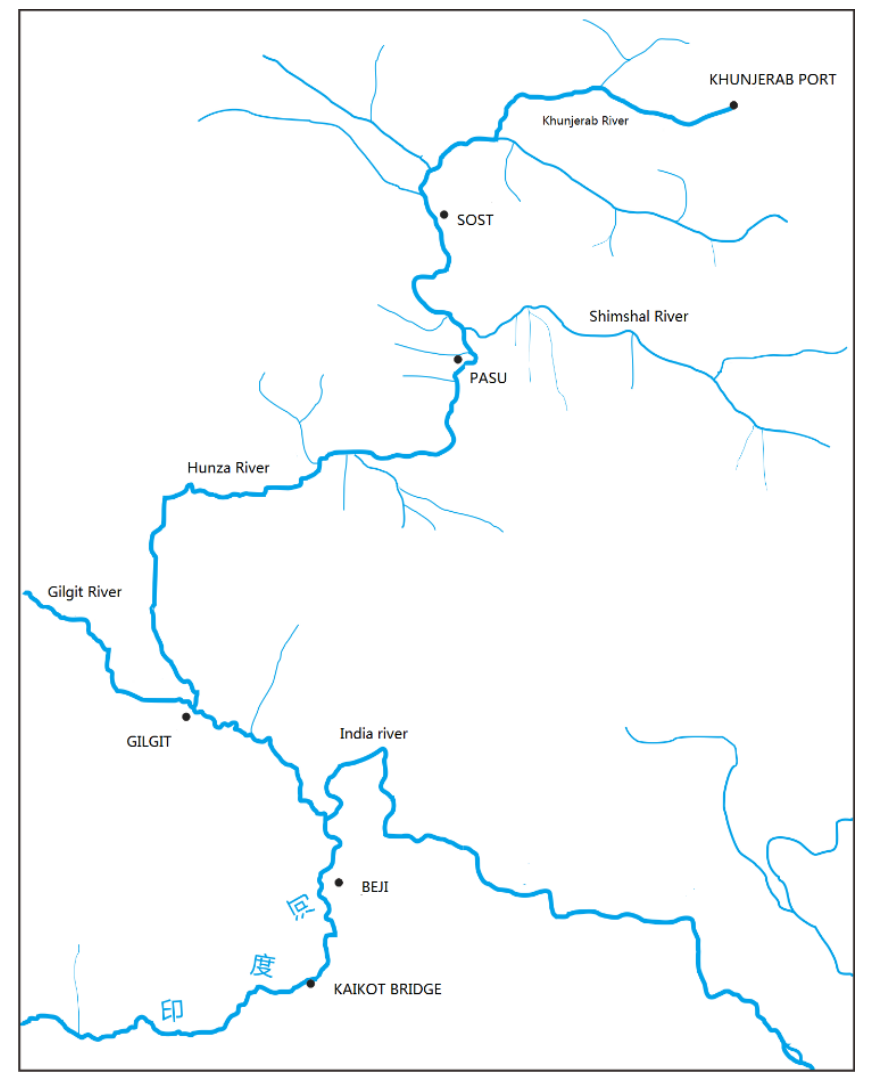

Figure 1 River systems along KKH

\section{Study Area Setting}

Since the Miocene, this region has been in an extrusive tectonic setting and tectonic activities are strong. The Indian Plate and the Eurasian Plate strongly collided and squeezed to the Pamir area, resulting in a huge overthrust structure. The orogenic belts of the Pamir, Karakoram, West Kunlun, and Hindu Kush strongly uplifted and horizontally extruded, forming an arc-shaped structure and thrust faults which projected generally northward. With the regional crust uplifted, river valleys were deeply cut. The valley terraces can be up to IV level or higher and most terraces are pedestal terraces with large elevation difference.

The Highway is located in the arid and semi-arid northern temperate climate zone of the South Asian subcontinent. The road runs from south to north with an altitude difference of nearly $4,000 \mathrm{~m}$, and the vertical climate is distinct. Alpine relief causes weather changes and is prone to extreme rainfall. The Hunza valley and its southern areas are in the northern temperate climate and the annual precipitation is between $600 \sim 1000 \mathrm{~mm}$. In summer rainfall is more concentrated. The northern Hunza is inland plateau mountain climate with small precipitation, thin air, strong solar radiation, low temperature. The minimum temperature here can reach minus $30 \mathrm{C}^{\circ}$.

There are mainly Quaternary loose sediments and magmatic rocks to be distributed along the Highway, followed by metamorphic rocks and sedimentary rocks. The Quaternary loose deposits are scattered over river valley floors, foothills, mountains, and ancient planation surface. There are types of sediments, including colluvial deposits, residual deposits, diluvial deposit, alluvial deposits, slope wash, and fluvioglacial accumulations.

Debris flow and other geological disasters are extremely developed along the Highway. Due to the limitation of regional geomorphology, the route of the highway is mainly placed along river valleys and hillside line. The end section of the northern Highway with $20 \mathrm{~km}$ is the ridge crossing line. Most of the main highway go through debris flow accumulation areas or circulation areas. The route positions are low, and debris flow disaster damages the roads almost every year. Field statistics showed that there were more than 150 debris flows along the Highway. Highway debris flow can be divided into four categories: rainfall-debris flow, rainfall-glacial debris flow, glacialglacial lake outburst debris flow, and freeze-thaw debris flow (Table 1).

Table 1. Distribution of four types of debris flows along $\mathrm{KKH}$

\begin{tabular}{ll}
\hline \multicolumn{1}{c}{ Type } & \multicolumn{1}{c}{ Distribution section } \\
\hline Rainfall debris flow & Distributed between Raikot (K470+500) and Dayaore (K538) of Hunza Valley \\
\hline Rainfall-glacier debris flow & Distributed between Dayore (K538) and Hasnabard (K623) \\
\hline Glacier-glacial lake outburst debris flow & Distributed between Hasnabard (K623) and Gosghil (K796) \\
\hline Freeze-thaw debris flow & Distributed between Gosghil (K796) and Khunjerab (K811) \\
\hline
\end{tabular}

\section{Particle Size Analysis of Riverbed Sediments}

\subsection{Particle size composition}

The grain size composition of riverbed sediments along the Highway is dominated by gravel and sand grains, and the content of clay particles and silt particles is very small. In Table 2, it shows the grain size data of riverbed deposits were collected within a range of more than 100 kilometers between chainage K670-K808 in the northern section of the Highway. The collecting positions of all the 45 samples were at places on floodplains. The field sampling was carried out by quartation method and each quantity was no less than 2 $\mathrm{Kg}$. The standard sieving method was used to complete the tests.

The experimental results showed that the composition of riverbed sediments was mainly composed of two groups, $>20$ $\mathrm{mm}$ and $>2 \mathrm{~mm}$, of which the percentage of $>20 \mathrm{~mm}$ grain group varied from $42.23 \%$ to $95.53 \%$ with an average of $68.10 \%$; >2 mm grain group was between $3.46 \%$ to $48.44 \%$ with an average of $20.89 \%$. 
Table 2 Grain size composition of the riverbed sediments along KKH

\begin{tabular}{|c|c|c|c|c|c|c|c|c|c|c|c|}
\hline No. & $\begin{array}{c}\text { Sampling } \\
\text { location }\end{array}$ & $20 \mathrm{~mm}$ & $>2 \mathrm{~mm}$ & $\begin{array}{l}>0.1 \\
\mathrm{~mm}\end{array}$ & $\begin{array}{l}0.1 \\
\mathrm{~nm}\end{array}$ & No. & $\begin{array}{c}\text { Sampling } \\
\text { location }\end{array}$ & $20 \mathrm{~mm}$ & $>2 \mathrm{~mm}$ & $\begin{array}{l}>0.1 \\
\mathbf{m m}\end{array}$ & $\begin{array}{l}<0.1 \\
\mathbf{m m}\end{array}$ \\
\hline 1 & & & & $20.86 \%$ & & 24 & & & & $9.78 \%$ & $22 \%$ \\
\hline 2 & $\mathrm{~K} 702+140$ & $76.68 \%$ & $11.48 \%$ & $11.65 \%$ & 0100 & 25 & $\mathrm{~K} 767+438$ & $85.21 \%$ & $9.17 \%$ & $5.44 \%$ & $0.18 \%$ \\
\hline 3 & K $705+690$ & $51.74 \%$ & & $12.20 \%$ & 0.0070 & 26 & $\mathrm{~K} 768+562$ & $84.26 \%$ & & $4.20 \%$ & $0.07 \%$ \\
\hline 4 & K711 & & & $9.15 \%$ & & 27 & & & & & $0.03 \%$ \\
\hline 5 & $\mathrm{~K} 711+940$ & $78.27 \%$ & $11.38 \%$ & $10.06 \%$ & 0.2370 & 28 & $\mathrm{~K} 771+065$ & $63.83 \%$ & $26.76 \%$ & $9.38 \%$ & $0.03 \%$ \\
\hline 6 & $\mathrm{~K} 719+510$ & $53.90 \%$ & $33.26 \%$ & $12.70 \%$ & $0.15 \%$ & 29 & $\mathrm{~K} 771+371$ & $95.53 \%$ & $3.46 \%$ & $1.01 \%$ & $0.01 \%$ \\
\hline 7 & $\mathrm{~K} 723+903$ & $56.33 \%$ & $36.00 \%$ & $7.65 \%$ & $0.02 \%$ & 30 & $\mathrm{~K} 771+380$ & & 22.9 & $5.66 \%$ & $0.03 \%$ \\
\hline 8 & $\mathrm{~K} 725+034.5$ & $60.91 \%$ & $25.75 \%$ & $13.03 \%$ & $0.31 \%$ & 31 & & & & $7.59 \%$ & $0.15 \%$ \\
\hline 9 & K736+590 & $58.62 \%$ & $35.36 \%$ & $5.98 \%$ & $0.04 \%$ & 32 & $\mathrm{~K} 779+610$ & $92.10 \%$ & 6.27 & $1.58 \%$ & $0.04 \%$ \\
\hline 10 & K736+590 & $79.58 \%$ & $13.63 \%$ & $6.60 \%$ & $0.19 \%$ & 33 & $\mathrm{~K} 780+030$ & $67.59 \%$ & & $8.35 \%$ & $0.15 \%$ \\
\hline 11 & $739+765$ & $95.24 \%$ & $2.95 \%$ & $1.80 \%$ & $0.01 \%$ & 34 & K780+665 & $59.23 \%$ & $31.49 \%$ & $9.17 \%$ & $0.12 \%$ \\
\hline 12 & $\mathrm{~K} 745+430$ & $61.50 \%$ & $10.16 \%$ & $27.88 \%$ & $0.45 \%$ & 35 & $\mathrm{~K} 781+100$ & $41.26 \%$ & $49.89 \%$ & $8.74 \%$ & $0.11 \%$ \\
\hline 13 & $\mathrm{~K} 745+980$ & $57.67 \%$ & $22.47 \%$ & $19.64 \%$ & $0.22 \%$ & 36 & $\mathrm{~K} 781+250$ & $57.21 \%$ & $32.65 \%$ & $9.97 \%$ & $0.18 \%$ \\
\hline 14 & $\mathrm{~K} 748+720$ & $78.80 \%$ & $11.17 \%$ & $9.95 \%$ & $0.08 \%$ & 37 & $\mathrm{~K} 786+200$ & $60.02 \%$ & $23.60 \%$ & $16.32 \%$ & $0.06 \%$ \\
\hline 15 & $751+270$ & $63.50 \%$ & $22.25 \%$ & $14.02 \%$ & $0.23 \%$ & 38 & $\mathrm{~K} 790+436$ & $87.03 \%$ & & $3.63 \%$ & $0.08 \%$ \\
\hline 16 & $\mathrm{~K} 753+895.3$ & $84.84 \%$ & $8.84 \%$ & $6.21 \%$ & $0.11 \%$ & 39 & $\mathrm{~K} 790+820$ & $52.76 \%$ & $32.87 \%$ & $14.32 \%$ & $0.05 \%$ \\
\hline 17 & K $756+090$ & $64.78 \%$ & $18.84 \%$ & $16.17 \%$ & $0.21 \%$ & 40 & & & $30.38 \%$ & $27.89 \%$ & $0.08 \%$ \\
\hline 18 & K756+783 & $50.14 \%$ & $26.61 \%$ & $23.03 \%$ & $0.22 \%$ & 41 & $\mathrm{~K} 792+623$ & $69.88 \%$ & $23.86 \%$ & $6.23 \%$ & $0.03 \%$ \\
\hline 19 & K756+980 & $60.14 \%$ & $19.94 \%$ & $19.71 \%$ & $0.22 \%$ & 42 & K794+820 & & $6.95 \%$ & $2.13 \%$ & $0.10 \%$ \\
\hline 20 & $\mathrm{~K} 760+740$ & $56.82 \%$ & $19.87 \%$ & $22.68 \%$ & $0.63 \%$ & 43 & $\mathrm{~K} 803+030$ & $83.77 \%$ & $11.06 \%$ & $5.00 \%$ & $0.17 \%$ \\
\hline 21 & K762+290 & $67.35 \%$ & $20.42 \%$ & $12.00 \%$ & $0.23 \%$ & 44 & $\mathrm{~K} 803+900$ & $76.81 \%$ & $14.13 \%$ & $8.76 \%$ & $0.30 \%$ \\
\hline 22 & & $77.77 \%$ & $9.81 \%$ & $11.97 \%$ & $0.45 \%$ & 45 & $\mathrm{~K} 808+700$ & $69.09 \%$ & $21.11 \%$ & $9.48 \%$ & $0.32 \%$ \\
\hline 23 & K766+940 & $78.74 \%$ & $10.89 \%$ & $10.09 \%$ & $0.28 \%$ & & Average & $68.10 \%$ & $20.89 \%$ & $10.85 \%$ & $0.17 \%$ \\
\hline
\end{tabular}

The particle size distribution curve of riverbed sediments along the Highway could be divided into two types, multimodal distribution and bimodal distribution, which actually reflect the mechanical composition and transportation process of the sediments. Using Krumbein's (1934) grading standard, $\varphi=-\log _{2} D$, the frequency curve of the particle size distribution of riverbed sediments is plotted in Figure 2.

(1) Unimodal distribution. Taking K719+510 (Figure 2(a)) as an example, the peak values $\varphi$ appear mostly around -4 , and the minor peaks $\varphi$ appear around 2 .

(2) Multimodal distribution (bimodal distribution). Taking K670+990 (Figure 2(b)), K736+590 (Figure 2(c)) as examples, The first peak is mostly in the $\varphi=-6 \sim-5$ range, the second peak is in the $\varphi=-5 \sim-4$ range, and the third peak is in the $\varphi$ range of $-3 \sim-2$ and $0 \sim 2$.
The shape of the particle size distribution curve of riverbed sediments collected at $\mathrm{KKH}$ is similar to that of debris flow deposits collected along KKH. The frequency curve of riverbed sediments is generally unimodal type and bimodal type. The main peak correspond to fine particles and the second peak is fine sand. Both the percentage of the peaks is not high, and the peak value is not prominent. Particle size distribution of debris flow deposits are generally multimodal type, a few are in bimodal distribution (Chen and Han 1986) (Figure 3). From the chart morphology, the curve shapes of both Figures $2 \& 3$ are similar.

The main channels of rivers along the Highway, such as the Gilgit River and the Hunza River, swayed and were cut deeply during drought period. The floodplains on both sides of the channels dried up and some of the streams became underground rivers. During summer and autumn, snow and 

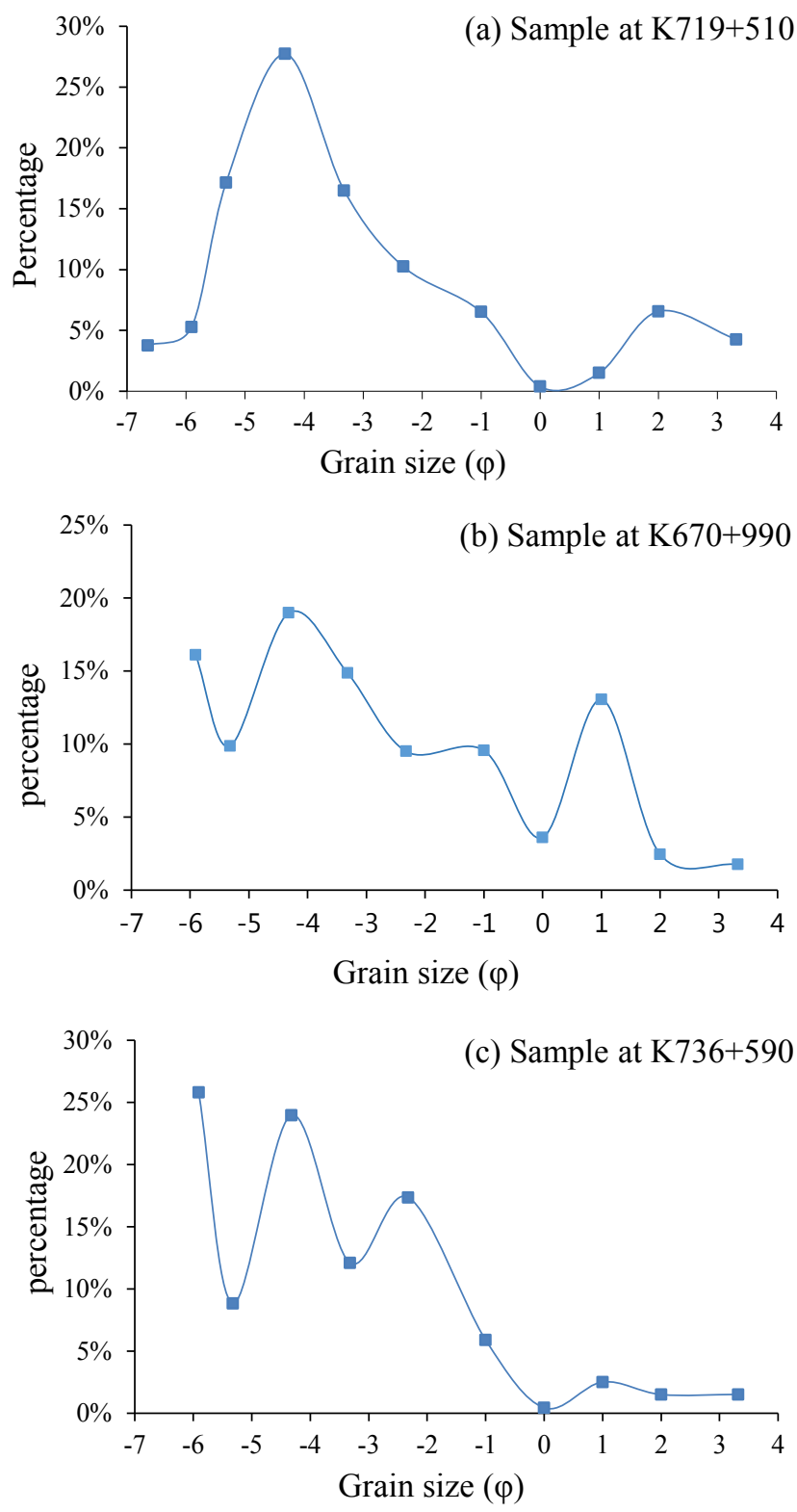

Figure 2 Grain size distribution in sediment samples

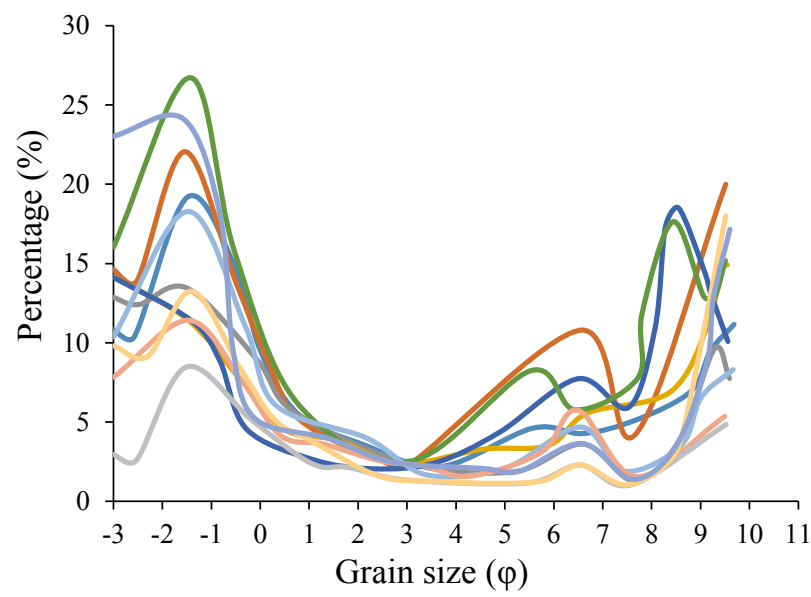

Figure 3 Grain-size distribution frequency curves of debris flow sediments in Wudu area (Chen and Han 1986) ice on mountains melted, and rainfall increased, followed by surface runoff increasing, and consequently debris flows broke out across the whole Highway. A large amount of fragmentary geo-material rushed out of valleys from both sides of the Highway, and they run over road, and drained into the main river and accumulated, and inevitably squeezed river channels, raising riverbed and flood the road. Although debris flow sediments stacked on the main river were partially transported by water erosion and subjected to flow separation effect, due to the bendy channel and low flow velocity, the conveyance capacity of channel stream was relatively insufficient. Therefore, debris flow deposits were transported with a relatively short distance with poor water separating effect. Debris flow deposits with high density and high viscosity have strong resistance to river erosion. Field survey found that debris flow deposited on floodplain were partially transported by water erosion, but the main components and composition were preserved. Therefore, the particle size distribution curve of the riverbed sediments in KKH should exhibited similarity to the one of debris flow deposits.

\subsection{Granularity parameters}

The grain size parameter numerically reflects the overall composition characteristics of samples. In this paper, the mean values $\left(M_{z}\right)$, median $\left(D_{50}\right)$, and sorting coefficient $\left(S_{d}\right)$, Skewness $\left(S_{k}\right)$ and kurtosis $\left(K_{u}\right)$ of the sediments from a total of 45 sampling points of K670+990 to K808+700 were analyzed using the method of moments (Krumbein 1955, Folk and Ward 1957, Folk 1966, Blott and Pye 2001). The calculation results are as follows:

Mean value: $M_{z}=\frac{\sum_{i=1}^{n} x_{i} f_{i}}{100}$

Coefficient of sorting: $S_{d}=\sqrt{\frac{\sum_{i=1}^{n}\left(x_{i}-M_{z}\right)^{2} f_{i}}{100}}$

Skewness: $\quad S_{k}=\frac{\sum_{i=1}^{n}\left(x_{i}-M_{z}\right)^{3} f_{i}}{100 S_{d}^{3}}$

Kurtosis: $\quad K_{u}=\frac{\sum_{i=1}^{n}\left(x_{i}-M_{z}\right)^{4} f_{i}}{100 S_{d}^{4}}$

Herein $f_{i}$ is the frequency percentage of each particle group $x_{i}$; the median value of each particle group.

\subsection{Results Analysis}

The result shows in Table 3.

(1) The mean value $M_{z}$ and median value of riverbed sediment particles $D_{50}$ are large, and the average size is mainly coarse grains. Analyzing the median of 45 samples (Table 3), we could see the fluctuations of the two indices, and then compared with the distribution of debris flow gullies along $\mathrm{KKH}$, the fluctuations and the positions of debris flow gullies have a certain corresponding relationship. The fitting median has $95 \%$ confidence interval with an 
upper limit of $50.3 \mathrm{~mm}$ and a lower limit of $21.9 \mathrm{~mm}$ (Figure 4). It can be seen that the average grain size of riverbed sediments is mainly coarse grains, which are similar to those of the debris flow sediments.

Table 3 Statistics of grain-size parameters of riverbed sediments

\begin{tabular}{|c|c|c|c|c|c|c|c|}
\hline Type of Debris Flows & No. & Sampling location & $M_{z}(\mathbf{m m})$ & $D_{50}(\mathrm{~mm})$ & $S_{d}$ & $S_{k}$ & $\boldsymbol{K}_{u}$ \\
\hline \multirow{36}{*}{$\begin{array}{l}\text { Glacier-glacial lake } \\
\text { outburst debris flow }\end{array}$} & 1 & K670+990 & 42.48 & 15.81 & 3.53 & 1.69 & 3.14 \\
\hline & 2 & $\mathrm{~K} 702+140$ & 96.15 & 51.27 & 3.65 & 2.26 & 5.71 \\
\hline & 3 & K705+690 & 46.84 & 21.51 & 3.00 & 1.94 & 4.38 \\
\hline & 4 & $\mathrm{~K} 711+310$ & 32.60 & 16.17 & 2.75 & 2.07 & 5.07 \\
\hline & 5 & $\mathrm{~K} 711+940$ & 105.06 & 54.35 & 3.22 & 2.23 & 5.73 \\
\hline & 6 & $\mathrm{~K} 719+510$ & 46.00 & 22.05 & 3.34 & 1.99 & 4.50 \\
\hline & 7 & $\mathrm{~K} 723+903$ & 47.55 & 24.56 & 2.74 & 1.97 & 4.63 \\
\hline & 8 & $\mathrm{~K} 725+034.5$ & 62.04 & 30.26 & 3.50 & 2.01 & 4.55 \\
\hline & 9 & $\mathrm{~K} 736+590$ & 56.39 & 25.66 & 2.80 & 1.96 & 4.67 \\
\hline & 10 & $\mathrm{~K} 736+590$ & 93.52 & 73.39 & 2.69 & 2.45 & 7.06 \\
\hline & 11 & $\mathrm{~K} 739+765$ & 114.56 & 72.47 & 1.77 & 3.07 & 13.72 \\
\hline & 12 & K745+430 & 76.17 & 41.97 & 4.28 & 1.74 & 3.24 \\
\hline & 13 & $\mathrm{~K} 745+980$ & 62.57 & 40.6 & 3.76 & 1.80 & 3.55 \\
\hline & 14 & $\mathrm{~K} 748+720$ & 93.19 & 66.1 & 3.13 & 2.39 & 6.41 \\
\hline & 15 & $\mathrm{~K} 751+270$ & 69.20 & 42.51 & 3.32 & 1.98 & 4.38 \\
\hline & 16 & K753+895.3 & 119.65 & 81.93 & 2.68 & 2.57 & 7.59 \\
\hline & 17 & K756+090 & 64.74 & 39.37 & 2.76 & 1.89 & 4.63 \\
\hline & 18 & $\mathrm{~K} 756+783$ & 51.22 & 20.17 & 3.92 & 1.71 & 3.19 \\
\hline & 19 & K756+980 & 64.39 & 36.37 & 4.61 & 1.03 & 1.72 \\
\hline & 20 & $\mathrm{~K} 760+740$ & 58.95 & 28.06 & 4.69 & 1.10 & 1.81 \\
\hline & 21 & K762+290 & 55.94 & 30.5 & 3.23 & 2.14 & 5.20 \\
\hline & 22 & $\mathrm{~K} 763+710$ & 91.24 & 49.94 & 3.45 & 2.21 & 5.50 \\
\hline & 23 & K766+940 & 93.74 & 67.08 & 3.03 & 2.32 & 6.05 \\
\hline & 24 & $\mathrm{~K} 767+210$ & 79.83 & 55.29 & 3.06 & 2.16 & 5.31 \\
\hline & 25 & $\mathrm{~K} 767+438$ & 110.87 & 103.45 & 2.34 & 3.62 & 12.74 \\
\hline & 26 & K768+562 & 112.17 & 83.29 & 2.18 & 3.70 & 12.81 \\
\hline & 27 & $\mathrm{~K} 770+770$ & 75.23 & 48.01 & 2.90 & 2.12 & 5.25 \\
\hline & 28 & K771+065 & 71.73 & 44.74 & 2.99 & 2.01 & 4.69 \\
\hline & 29 & $\mathrm{~K} 771+371$ & 120.53 & 74.91 & 1.85 & 1.67 & 6.20 \\
\hline & 30 & $\mathrm{~K} 771+380$ & 76.11 & 47.64 & 2.45 & 2.55 & 6.89 \\
\hline & 31 & $\mathrm{~K} 772+343$ & 76.25 & 46.7 & 2.77 & 2.25 & 6.01 \\
\hline & 32 & K779+610 & 109.88 & 71.43 & 1.83 & 2.74 & 10.84 \\
\hline & 33 & K780+030 & 68.82 & 41.01 & 3.45 & 1.14 & 2.28 \\
\hline & 34 & K780+665 & 63.16 & 31.69 & 3.46 & 1.20 & 2.26 \\
\hline & 35 & $\mathrm{~K} 781+100$ & 43.91 & 10.5 & 3.24 & 1.57 & 2.80 \\
\hline & 36 & $\mathrm{~K} 781+250$ & 58.52 & 27.34 & 3.06 & 1.91 & 4.23 \\
\hline
\end{tabular}


Continued:

\begin{tabular}{|c|c|c|c|c|c|c|c|}
\hline Type of Debris Flows & No. & Sampling location & $M_{z}(\mathbf{m m})$ & $D_{50}(\mathrm{~mm})$ & $S_{d}$ & $S_{k}$ & $\boldsymbol{K}_{u}$ \\
\hline \multirow{7}{*}{$\begin{array}{l}\text { Glacier-glacial lake } \\
\text { outburst debris flow }\end{array}$} & 37 & $\mathrm{~K} 786+200$ & 62.66 & 34.6 & 3.57 & 1.92 & 4.10 \\
\hline & 38 & $\mathrm{~K} 790+436$ & 111.26 & 95.32 & 2.24 & 2.78 & 9.29 \\
\hline & 39 & K790+820 & 57.90 & 24.1 & 3.68 & 1.75 & 3.41 \\
\hline & 40 & $\mathrm{~K} 791+120$ & 34.83 & 40.29 & 3.93 & 1.69 & 3.09 \\
\hline & 41 & $\mathrm{~K} 792+623$ & 66.94 & 33.02 & 3.36 & 1.06 & 2.23 \\
\hline & 42 & $\mathrm{~K} 794+820$ & 103.11 & 68.39 & 1.68 & 0.68 & 5.47 \\
\hline & Average & & 74.95 & 46.04 & 3.09 & 2.02 & 5.39 \\
\hline \multirow{4}{*}{$\begin{array}{l}\text { Freeze-thawing } \\
\text { debris flow }\end{array}$} & 43 & $\mathrm{~K} 803+030$ & 123.46 & 75.69 & 2.11 & 2.39 & 8.47 \\
\hline & 44 & $\mathrm{~K} 803+900$ & 131.56 & 105.97 & 3.21 & -0.14 & 1.45 \\
\hline & 45 & $\mathrm{~K} 808+700$ & 76.40 & 41.27 & 3.52 & 0.14 & 0.74 \\
\hline & Average & & 110.47 & 74.31 & 2.95 & 0.80 & 3.55 \\
\hline
\end{tabular}

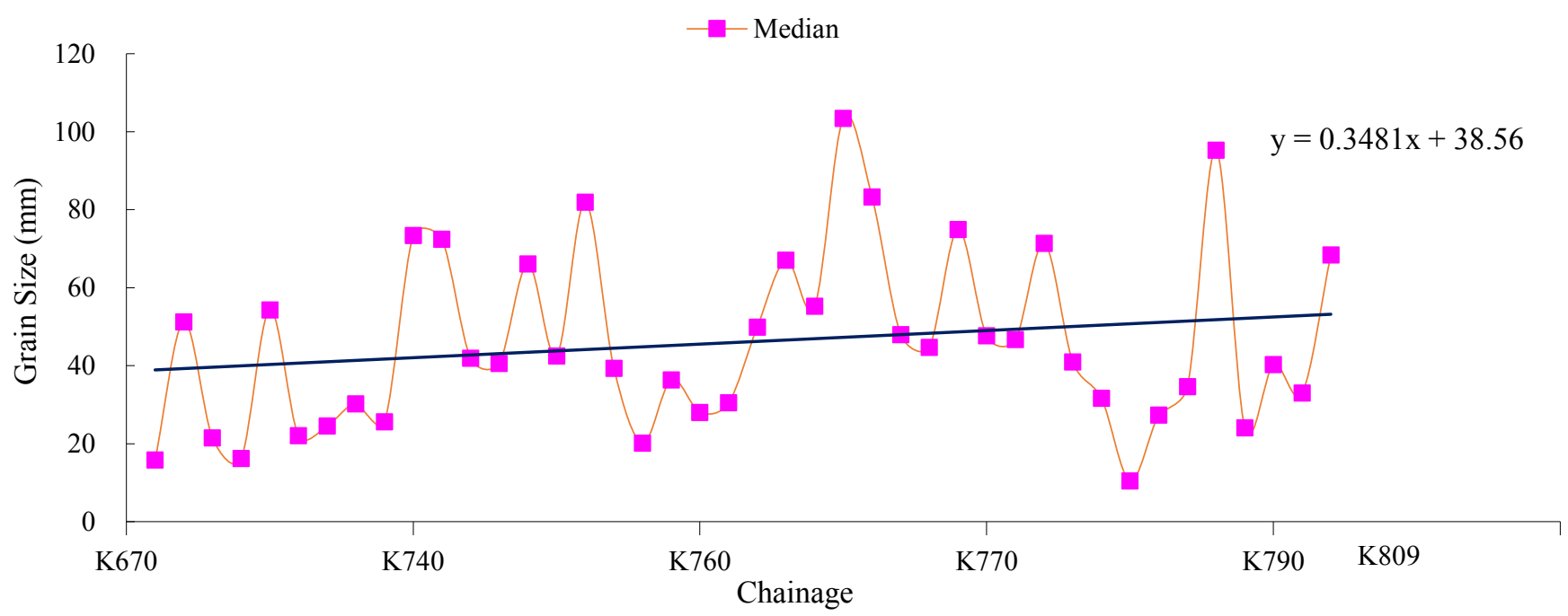

Figure 4 Median change of grain-size of riverbed sediments

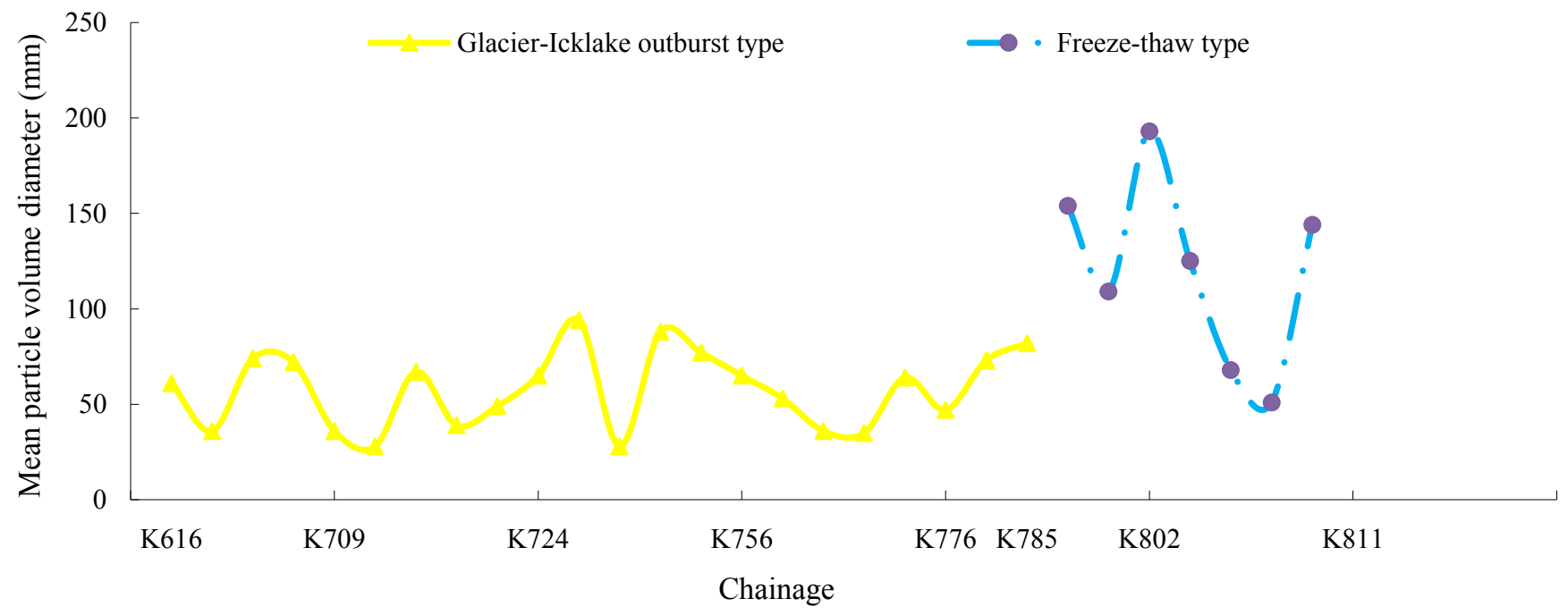

Figure 5 Schematic diagram of the mean particle volume diameter distribution of debris flow along KKH 
Minitab 16 software was used to perform regression analysis on the variation tread of median (Figures $4 \& 5$ ). The regression equation of the median $y=0.5131 x+36.127$ was obtained with $P$ value 0.062 , which was higher than the pre-selected $\alpha$ level $(P=0.05)$ but not much. Basically, it can be considered that the relationship is significant. As evaluated by the residual normal probability plot of $D_{50}$, we can see that the residual basically obeys a straight line (Figures $6 \& 7$ ), indicating that the residuals of the two basically obey the normal distribution.
Analysis of regression: $D_{50}$. The regression equation is: $D_{50}=36.13+0.5131$ number $S=23.3322 ; R-S q=7.9 \% ; R-S q(a d j)=5.7 \%$

\begin{tabular}{llllll}
\hline \multicolumn{2}{l}{ Analysis of Variance } & & & & \\
\hline Source & DF & SS & MS & F & P \\
\hline Regression & 1 & 1998.0 & 1998.02 & 3.67 & 0.062 \\
Residual Error & 43 & 23408.8 & 544.39 & & \\
Total & 44 & 25406.8 & & & \\
\hline
\end{tabular}

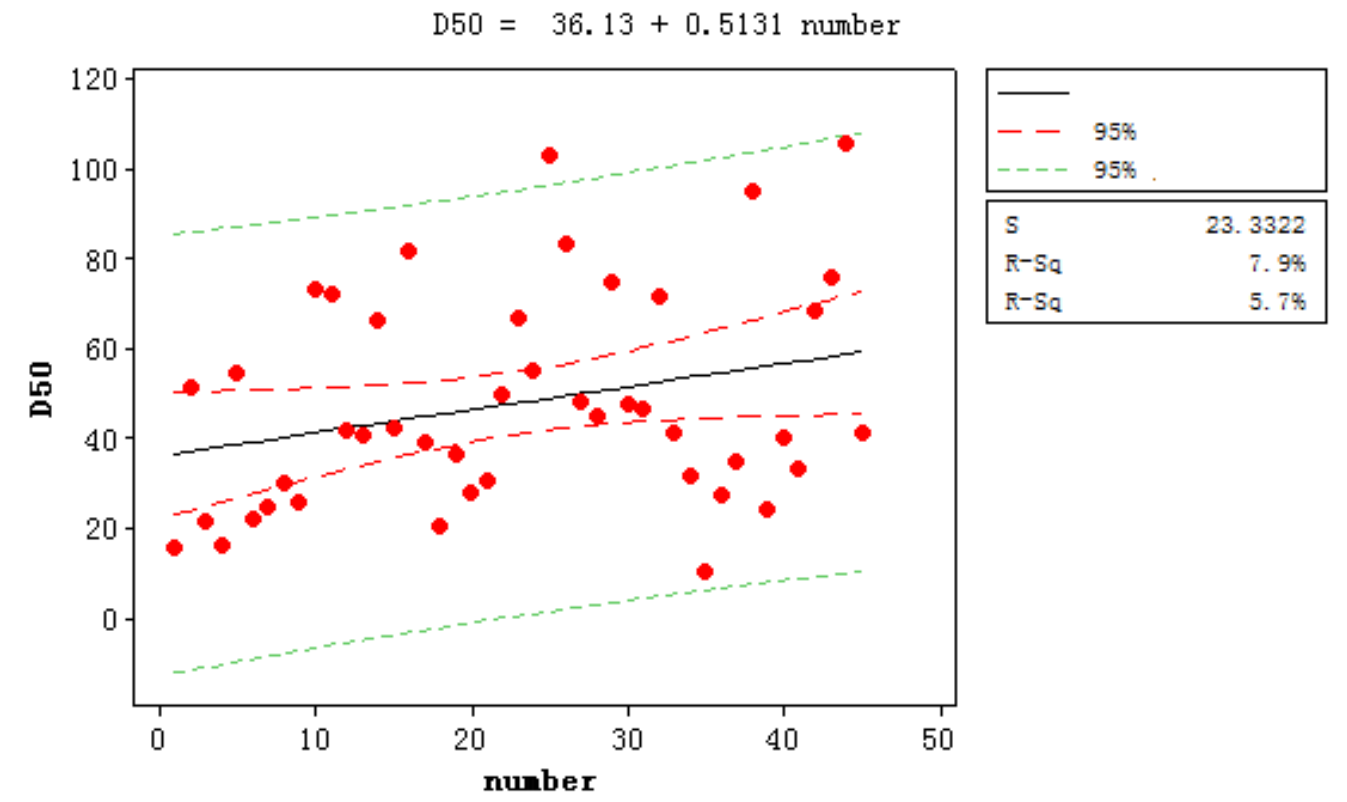

Figure 6 The $95 \%$ confidence interval and $95 \%$ prediction interval of $D_{50}$ fitting line

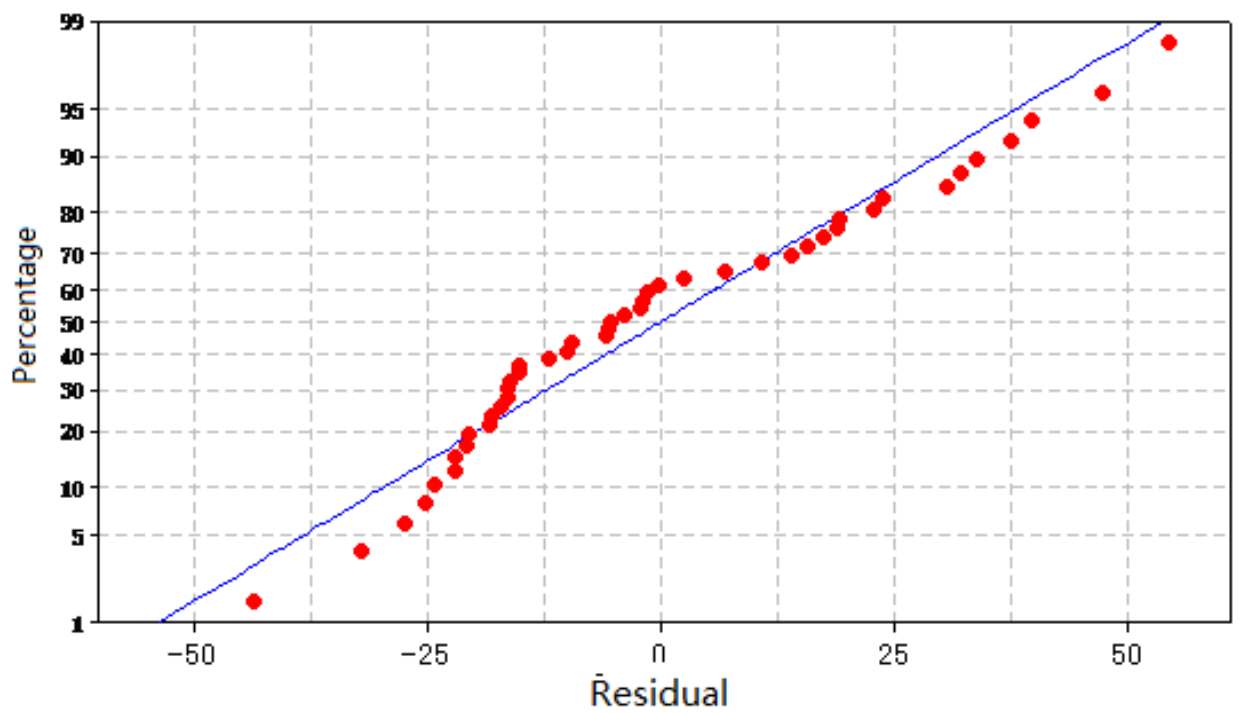

Figure 7 The normal probability plot of $D_{50}$ residual error 
Table 4 Standards for granularity parameters (Blott and Pye 2001)

\begin{tabular}{cccccc}
\hline \multicolumn{2}{c}{ Degree of sorting $\left(\boldsymbol{S}_{\boldsymbol{d}}\right)$} & \multicolumn{2}{c}{ Skewness $\left(\boldsymbol{S}_{\boldsymbol{k}}\right)$} & \multicolumn{2}{c}{ Kurtosis $\left(\boldsymbol{K}_{\boldsymbol{u}}\right)$} \\
\hline$<0.35$ & Excellent & $>+1.3$ & Very right-skewed & $<1.7$ & Extremely wide peak \\
\hline $0.35 \sim 0.50$ & Very good & $+0.43 \sim+1.3$ & Right-skewed & $1.7 \sim 2.55$ & Wide peak \\
\hline $0.50 \sim 0.70$ & Good & $-0.43 \sim+0.43$ & Symmetry & $2.55 \sim 3.7$ & Normal peak \\
\hline $0.70 \sim 1.00$ & Fine & $-0.43 \sim-1.3$ & Left-skewed & $3.7 \sim 7.4$ & Narrow peak \\
$1.00 \sim 2.00$ & Poor & $<-1.3$ & Extremely left-Skewed & $>7.4$ & Extremely narrow peak \\
\hline $2.00 \sim 4.00$ & Poor & & & & \\
\hline$>4.00$ & Poor & & & & \\
\hline
\end{tabular}

Since the type of debris flow developed along the highway in the area where the sampling was conducted is mainly glacial-glacial lake outburst debris flow and freezethaw debris flow, the average value of the riverbed sediments at the 45 sampling points were compared with the average particle volume diameter of the two types of debris flow deposits. It can be found that in the zone of glacial-glacial lake outburst debris flows the average value of particle size of the sediments collected at 42 sampling points (K670+990 to K794+820) ranged from $53.8 \mathrm{~mm}$ to $85.4 \mathrm{~mm}$ with a $95 \%$ confidence interval. The average value of the three points in the distribution zone of the freeze-thaw debris flow (K803+030 to K808+700) was between $76.4 \mathrm{~mm}$ and 123.5 $\mathrm{mm}$, basically equal to the average particle volume diameter of the debris flow deposits in the vicinity (where the average particle volume diameter of glacial-glacial lake outburst debris flows is $33.6 \mathrm{~mm}$ to $70.9 \mathrm{~mm}$ with a $95 \%$ confidence interval, and the freeze-thaw debris flow is $52.6 \mathrm{~mm}$ to 265.9 $\mathrm{mm}$. The variation range (Figure 5) remains the same.

(2) The sorting coefficient of 45 riverbed sediment samples is relatively large, with a range from 1.68 to 4.69 , indicating that the sediment sortability is poor. The mean value of sorting coefficient for the glacier-glacial lake outburst debris flows was 3.09 , and the mean value for the freeze-thaw debris flow zone was 2.95. According to the classification criteria (Table 4) given by Blott and Pye 2001, it falls within the range of poor sorting to very poor sorting. Among them there were $8.9 \%$ (4) poor sorting, $84.4 \%$ very poor sorting (38) and extremely poor sorting $6.7 \%$ (3). The analysis results show that the sediments are poorly sorting or extremely poor sorting, which is the same as the poor or very poor sorting of debris flow sediments (Institute of Mountain Hazards \& Environment 2000). At the same time, this distributional feature also confirms that the riverbed sediments should have not been significantly modified after entering the new environment, and the sediment transport distance is short, and the riverbed sediments are closer to its source area.

(3) The skewness was dominated by right-skewed, indicating that the riverbed sediments were coarser in size. Except the K803+900 sampling point were left-skewed, the other 44 samples were all right-skewed, ranging from -0.14 to 3.70. According to the classification standard given by Blott and Pye (2001), it belongs to the range from symmetry to extreme right-skewed. Among them, $4.4 \%$ (2) are symmetric, $11.1 \%$ (5) are right-skewed, and $84.5 \%$ (38) are extremely right-skewed. The results showed that the sediment size was coarser, mainly in the coarse fraction, which was similar to the distribution characteristics of debris flows sediments whose composition are characterized by right-skewed size distribution and the coarse-grained material composition are dominant (Zhu et al 2014a).

(4) The kurtosis is mainly narrow peak type. Among the 45 kurtosis values, there were 7 extremely broad and broad peaks, accounting for $15.6 \%$ of the total, while the narrow and very narrow peaks accounted for $71.1 \%$ (32). According to the classification criteria, it can be seen that the particle size distribution of riverbed sediments is mostly narrow peak type, which is consistent with the poor granularity of riverbed sediments obtained as above.

The characteristics of the average particle size distribution, the sorting coefficient, the skewness, the kurtosis and other parameters of the riverbed sediments at the 45 sampling points indicated that the riverbed sediments had similar grain size distribution characteristics to the debris flow sediments. This suggested that the river sediments in the area mainly come from the supply of debris flows on both sides of the Highway. Debris flow sediments entered the river and have not been significantly modified since they were transported in a short distance. Therefore, they exhibited similar distribution characteristics with debris flow sediments.

\section{Conclusion}

Through this study, the following conclusions were drawn:

(1) The particle size composition of riverbed sediments along KKH was dominated by coarse grains such as gravel and sand. The main characteristics of grain size distribution are bimodal or multimodal distributions, consistent with the composition characteristics of debris flow sediments. Corresponding to the debris flow distribution zone, the average particle size of the riverbed sediment particles was basically the same as the average particle volume diameter range of the local debris flow deposits.

(2) The granularity parameters of riverbed sediments are similar to those of debris flow sediments, which suggested that the river sediments along KKH mainly come from the supply of debris flow sediments in the same watershed basin. 


\section{Acknowledgement}

This research is supported by the National Natural Science Foundation of China under contract number of 10472045 , and the Science Foundation of Ministry of Transport of China under contract number of 05B52010. During the period from 2006 to 2011, the project has conducted five joint field investigations by Chinese and Pakistani scientists. The field work has been supported by the Engineering Project Department of China Road and Bridge Engineering Co., Ltd. and the First Highway Survey and Design Institute of China Communications. Prof. M. Asif Khan TI, director of the National Centre of Excellence in Geology, Pakistan, Prof. M. Haneef, director of Geology Department, University of Peshawar, Pakistan, Prof. Irshad Ahmad, University of Engineering \& Technology, Peshawar, Department of Civil Engineering, Pakistan and other Pakistani researchers participated in the joint inspections and academic seminars. Dr. GE Yonggang, a researcher of the Chengdu Institute of the Chinese Academy of Sciences, and Dr. PEI Laizheng, participated in the inspection in September 2008. Professor Han Yongshun from Hunan University of Science and Technology participated in the inspection in July 2011. Hereby thank them all.

\section{References}

Blott, S.J. and K. Pye, 2001. Gradistat: a grain size distribution and statistics package for the analysis of unconsolidated sediments. Earth Surface Processes and Landforms, 26: 1237 - 1248.

Chen, H.L. and M. Han, 1986. Size analysis of debris flow in Wudou Region and its characterisitic. In: Debris flow Conference Proceeding. Sichuan Science and Technology Press: Lanzhou. p.141 - 147. (in Chinese)

Folk, R.L. and W.C. Ward, 1957. Brazos River bar: a study in the significance of grain size parameters. Journal of Sedimentary Research, 27: 13 - 26.

Folk, R.L., 1966. A review of grain-size parameters. Sedimentology, 6(2): 73 - 93.

Group, T.B.G.I., 1979. The Batura Galcier in the Karakoram Mountain and its variations. Scientia Sinica, 2(8): 958 974.
Institue of Mountain Hazards \& Environment, Chinese Acedemy of Sciences. Debris Flow in China. 2000, Beijing: Business Press. (in Chinese)

Krumbein, W.C., 1934. Size frequency distributions of sediments. Journal of Sedimentary Research, 4(2): 65 77.

Krumbein, W.C., 1955. Graphic presentation and statistical analysis of sedimentary data. In: Recent Marine Sediments. SEPM (Society for Sedimentary Geology). p.558 - 591.

Mool, P.K., S.R. Bajracharya, B. Shrestha, S.P. Joshi, R. Roohi, A. Ashraf, R. Naz, S.A. Hussain and M.H. Chaudhry, 2005. Inventory of Glaciers and Glacial Lakes and Identification of Potential Glacial Lake Outburst Floods (GLOFs) Affected by Global Warming in the Mountains of Himalayan Region. Pakistan Agricultural Research Council (PARC), International Centre for Integrated Mountain Development (ICIMOD). p.334.

Shi, Y.F. and W. Wang, 1980. Research on snow-cover in China and the avalanche phenomena of Batura Glacier in Pakistan. Journal of Glaciology, 26: 25 - 30.

Shi, Y.F., T. Hsieh, P. Cheng and C.C. Li, 1980. Distribution, Features and Variations of Glaciers in China. In: Proceedings of the Riederalp Workshop, September 1978. IAHS-AISH Publ. p.111 - 116.

Zhang, X., 1980. Recent variations in the glacial termini along the Karakorum Highway. Journal of Geographical Science, 35(2): 149 - 160. (in Chinese)

Zhang, X., 1984. Recent variations of some glaciers in the Karakoram Mountains. In: K.J. Miller (ed), The International Karakoram Project. Cambridge University Press: Islamabad, Pakistan. p.39 - 50.

Zhu, Y.Y., Z.Q. Yang, S. Zou, M. Waseem and C.Y. Ye, 2014 a. Glacialized geomorphological geohazard along ChinaPakistan International Karakoram Highway. Journal of Caastrophology, 29(3): 81 - 90. (in Chinese)

Zhu, Y.Y., Z.Q. Yang, S. Zou, M. Waseem and C.Y. Ye, 2014b. Glacier geo-hazards along China - Pakistan International Karakoram Highway. Journal of Highway and Transportation Research and Development, 31(11): 51 - 59. (in Chinese) 